\title{
Sensitive Analytical Liquid Chromatography-Tandem Mass Spectroscopy Method for the Estimation of Dexlansoprazole in Pharmaceutical Formulations
}

\author{
Rinchi Bora ${ }^{1}$, S.T. Narenderan ${ }^{1}$, B. Babu ${ }^{1}$, S.N. Meyyanathan ${ }^{1 *}$, Abel Jacob George ${ }^{1}$, M. Kalaivani ${ }^{2}$ \\ ${ }^{1}$ Department of Pharmaceutical Analysis, JSS College of Pharmacy (JSS Academy of Higher Education and Research, Mysuru) Udhagamandalam, Tamil \\ Nadu, India. \\ ${ }^{2}$ Indian Pharmacopoeia Commission, New Delhi
}

\begin{tabular}{l}
\hline ARTICLE INFO \\
\hline Article history: \\
Received on: 07/03/2018 \\
Accepted on: 23/04/2018 \\
Available online: $30 / 07 / 2018$
\end{tabular}

Key words:

Dexlansoprazole,

Omeprazole, LC-MS/

MS, Validation, ICH,

Electrospray Ionization.

\begin{abstract}
A sensitive LC-MS/MS method has been developed and validated for the quantitative determination of Dexlansoprazole from the commercially available formulations. Omeprazole was used as the internal standard. Isocratic separation was achieved using Zorbax SB $\mathrm{C}_{18}$ column $(4.6 \times 100 \mathrm{~mm}, 3 \mu \mathrm{m})$ as a stationary phase and the mobile phase consists of $(0.5 \mathrm{mM})$ Ammonium Acetate adjusted to $\mathrm{pH} 3.5$ : acetonitrile $(30: 70 \mathrm{~V} / \mathrm{V})$ with a flow of $0.5 \mathrm{~mL} / \mathrm{min}$. Detection was carried out by triple quadrupole mass spectrometry with electrospray ionization in positive mode with proton adducts at $\mathrm{m} / \mathrm{z} 370.05$ to 251.95 and 346.00 to 198.05 to monitor Dexlansoprazole and Omeprazole. The linearity of the method was found over a concentration range of $0.5-3000 \mathrm{ng} / \mathrm{mL}$ with a regression analysis of 0.9994 . The percentage recovery of the present method was found to be 94.33 to $99.97 \%$. The LC-MS/MS method was validated as per ICH guidelines. The developed method can be successfully applied for the estimation of Dexlansoprazole in the commercial formulation and in bulk drug.
\end{abstract}

\section{INTRODUCTION}

Dexlansoprazole

2-(R)-(+)-2-([3-methyl-4-(2,2,2 trifluoroethoxy)pyridine-2-yl]methylsulfinyl)-1H-benzo[dimidazole)\} is a proton pump inhibitor (Figure 1). It is an enantiomer of lansoprazole (Nagaya, 1990; Metz, 2009). Dexlansoprazole is commercially available as delayed-release capsules (30 and 60 mg) (Dexilant, 2017; Dexlanzoprazole, 2017). Dexlansoprazole is used in the healing of erosive esophagitis, in maintaining of healed erosive esophagitis and non-erosive gastroesophageal reflux disease (Barbara and Radwan, 2015; Aslam et al., 2009) (GERD) associated with heartburn.

The literature survey revealed a stability method and an analytical method for Dexlansoprazole (DLP) was estimated by

"Corresponding Author

S.N. Meyyanathan, Department of Pharmaceutical Analysis, JSS

College of Pharmacy, Ootacamund, (JSS Academy of Higher Education and Research, Mysuru)-643 001, India.

E-mail: snmeyyanathan@jssuni.edu.in
HPLC (Hotha et al., 2012; Sriharshaet al., 2015; Yanamadala et $a l ., 2013)$ and to best of our knowledge, liquid chromatographytandem mass spectroscopy has been previously reported in human plasma.

The aim of the current study was to develop a highly sensitive method for the estimation of Dexlansoprazole bulk and formulations and validate as per ICH guidelines (ICH, 1996).

\section{MATERIALS AND METHODS}

\section{Materials}

Working standard of Dexlansoprazole was provided as a gift sample from Indian Pharmacopoeia Commission, New Delhi, India and internal standard Omeprazole was purchased from Drugs testing laboratory, JSS College of Pharmacy, Ooty, India. Acetonitrile of LC-MS/MS grade by Sigma Aldrich, Ammonium Acetate by Rankem Fine Chemical Limited and Water of LC-MS/ MS grade from Milli-Q RO system (Millipore, Bedford, USA) were used. 


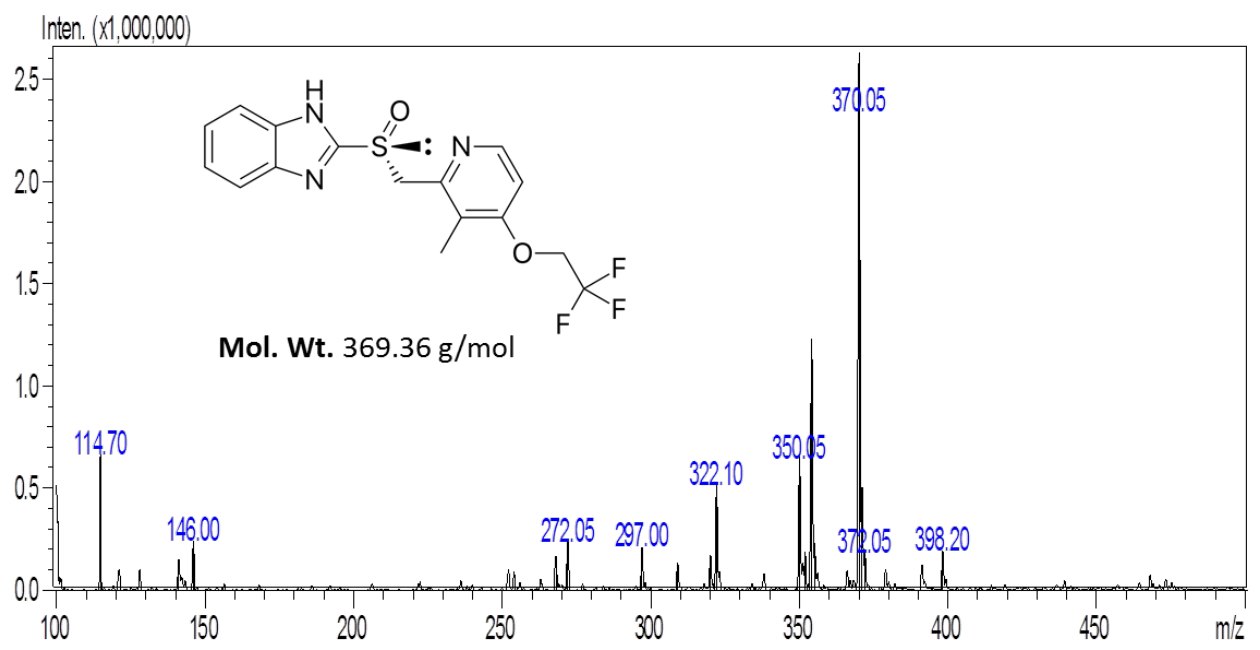

Fig. 1: Mass scan spectra of dexlansoprazole in positive mode.

\section{Equipment and chromatographic conditions}

LC system coupled with tandem quadrupole mass spectrometry (Shimadzu 8030, Tokyo Japan) equipped with electrospray ionization (ESI) interface, LC-20AD pump, SPDM20 PDA detector, CTO-20AC column oven, CBM-20 alite controller and SIL-20AC autosampler was used. The data were recorded using Lab solution data station software. Isocratic separation was achieved using Zorbax $\mathrm{SB} \mathrm{C}_{18}$ column $(4.6 \times 50$ $\mathrm{mm}, 3 \mu \mathrm{m})$ as a stationary phase and the mobile phase consists of $(0.5 \mathrm{mM})$ Ammonium acetate $(\mathrm{pH} 3.5)$ : acetonitrile $(30: 70 \mathrm{~V} / \mathrm{V})$ with a flow of $0.5-\mathrm{mL} / \mathrm{min}$ and injection volume of $10 \mu \mathrm{l}$ was employed.

\section{Selection of a mass range}

A $1000 \mathrm{ng} / \mathrm{mL}$ of Dexlansoprazole and Omeprazole was infused into the mass spectrometer directly and the conditions for the operation were optimized. Obtained transitions were $255 \rightarrow 237.1$ and $195 \rightarrow 138.1 \mathrm{~m} / \mathrm{z}$ was used to monitor Dexlansoprazole and Omeprazole (IS) (Figure 2b).

\section{Sample preparation}

\section{Preparation of working standard solution}

Dexlansoprazole was dissolving in $10 \mathrm{~mL}$ of acetonitrile to produce a concentration of $1 \mathrm{mg} / \mathrm{mL}$. The stock solution was refrigerated at $2-8^{\circ} \mathrm{C}$ and stored. Further, the working solutions were obtained by diluting the stock solution with diluent acetonitrile.

\section{Preparation of working omeprazole solution (IS)}

Omeprazole solution was dissolving in $10 \mathrm{~mL}$ of acetonitrile to produce a stock solution of $1 \mathrm{mg} / \mathrm{mL}$. The stock solution was refrigerated at $2-8^{\circ} \mathrm{C}$ and stored. Further, working solutions were obtained by diluting the stock solution with diluent acetonitrile.

\section{Preparation of sample solution}

Dexlansoprazole equivalent to $0.10 \mathrm{~g}$ was taken in a volumetric flask and dissolved in methanol and marked up with acetonitrile to get $10 \mu \mathrm{g} / \mathrm{mL}$. Further dilution of the above solution with the diluent acetonitrile to produce the concentration of 15 , 750, $2500 \mathrm{ng} / \mathrm{mL}$ (LQC, MQC, and HQC).

\section{Method validation}

Validation of the method for specificity, linearity, accuracy, precision, range, quantitation limit, and detection limit, robustness, and system suitability as per the $\mathrm{ICH}$ guidelines $(\mathrm{ICH}$, 1996).

\section{Specificity}

The analyte response measurement in the presence of other drugs, excipients, and their potential impurities can be termed as specificity.

\section{Linearity}

The average of six determinations at ten concentration levels covering the range of $0.5-3000 \mathrm{ng} / \mathrm{mL}$ for DLP, the evaluation of linearity was performed. Calculation of the coefficient correlation, slope and intercept values was done by using calibration curve for linearity evaluation.

\section{Accuracy}

The accuracy of the method was determined by recovery studies according to ICH guidelines. The pre-analyzed samples were spiked with standard drug DLP.

\section{Precision}

Evaluation of precision was carried out by inter-day and intra-day precision. Study samples consisted of three concentration levels (six replicates) of low (LQC), medium (MQC) and high (HQC) quality controls, i.e. $15,750,2500 \mathrm{ng} / \mathrm{mL}$, respectively. The report used for precision was from the regressed concentration of the percent relative standard deviation (\%RSD).

\section{Limit of detection (LOD) and limit of quantification (LOQ)}

Determination of LOD and LOQ was by the signal-tonoise ratio. LOD ratio was 3:1 whereas LOQ, the drug could be quantified with minimum peak area in the ratio of 10:1. 


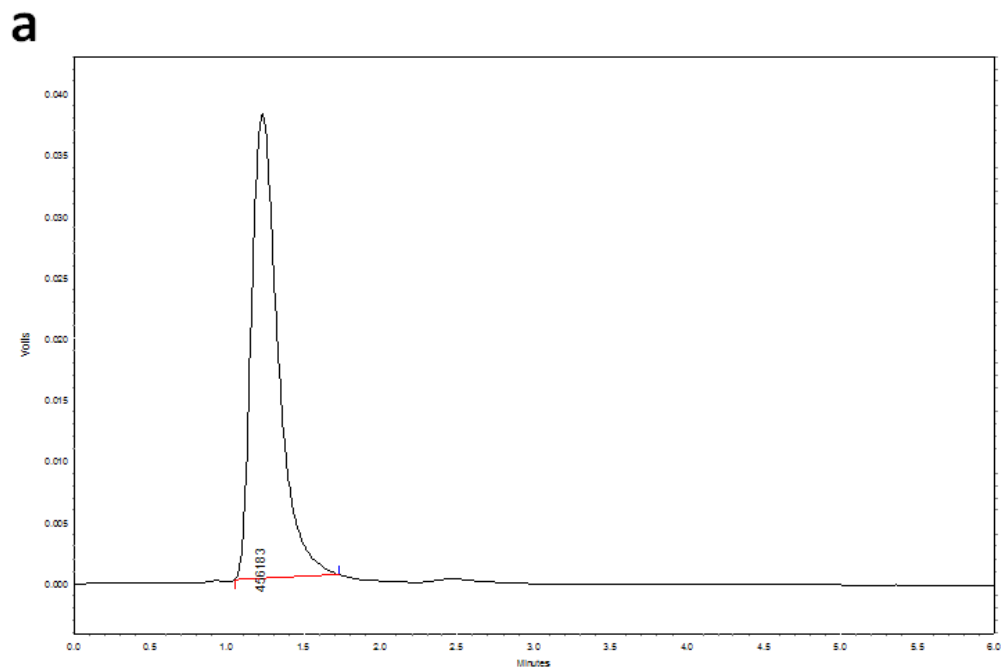

b
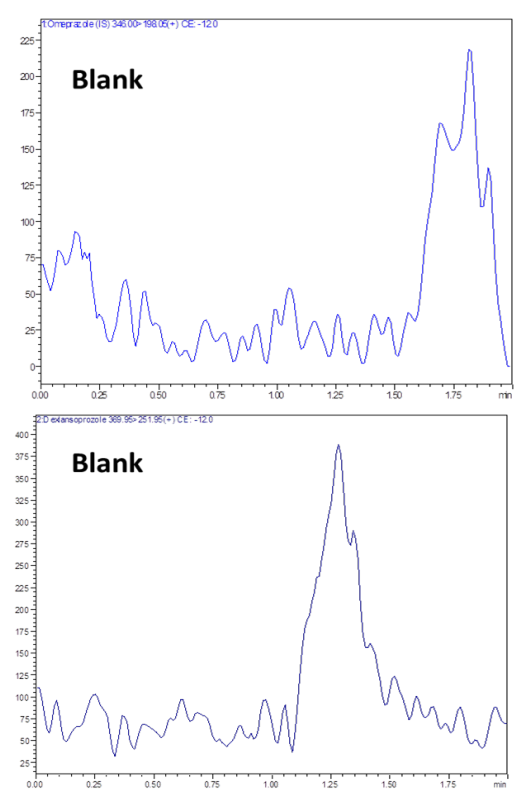
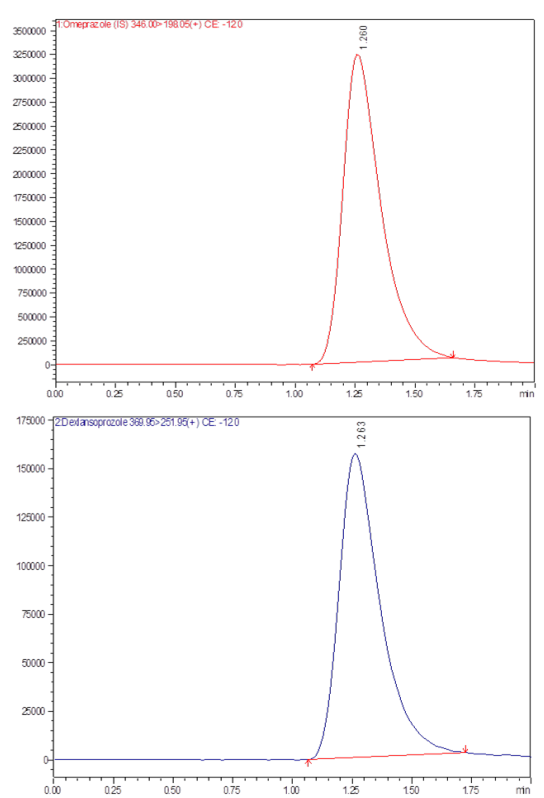

Fig. 2: (a) Typical HPLC chromatogram of dexlansoprazole in the formulation and (b) Typical LC-MS/MS chromatogram of dexlansoprazole in the formulation.

\section{Robustness}

The alteration in the condition of the experiment like operators, the source of reagents, similar type column and optimized conditions like $\mathrm{pH}$, mobile phase ratio, and flow rate were studied for the robustness of the method.

\section{System suitability}

For method development, the test for system suitability is an integral part. Three replicates injections of the sample solution were evaluated for retention time (RT), a number of theoretical plates $(\mathrm{N})$ and Tailing factor $(\mathrm{T})$.

\section{RESULTS AND DISCUSSION Specificity}

To determine that the excipients used are not interfering with the main compound peak, test for specificity needs to be done. No peaks were eluted along with the retention time of DLP (Figure 2a). Hence, the developed method results showed that it was selective for determination of DLP in the formulation.

\section{Calibration curve}

The evaluation of the method to be linear was by six determinations at ten concentration levels with a range of 0.5 $3000 \mathrm{ng} / \mathrm{mL}$ for DLP and the standard deviation (SD) were found to be within the limits. A calibration curve was found to be linear with a mean regression of equation $\left(\mathrm{Y}=15.944 \mathrm{x}+538.34, \mathrm{r}^{2}=\right.$ 0.99942 , S.D. $=0.68)$ respectively, where the analyte peak area ratio to the IS (Omeprazole) is the $\mathrm{Y}$ and the analyte concentration in $\mathrm{ng} / \mathrm{mL}$ is the $\mathrm{X}$ (Figure 3 ). 


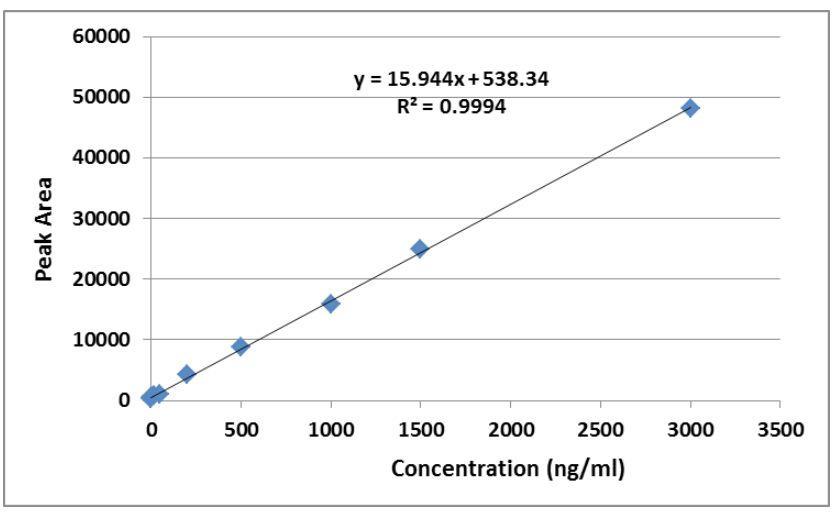

Fig. 3: Calibration curve of Dexlansoprazole at ten concentration levels (0.5$3000 \mathrm{ng} / \mathrm{mL})$.

\section{Accuracy}

The accuracy of the method was carried out for three quality control (LQC, MQC, and HQC) samples by standard addition method, and the accuracy was found to be 96.00 to $99.83 \%$. Application of the developed method for the estimation of a commercial formulation of DLP (Table 1).

Table 1: Accuracy and precision studies for the determination of Dexlansoprazole.

\begin{tabular}{cccccc}
\hline \multirow{2}{*}{$\begin{array}{c}\text { QC } \\
\text { samples }\end{array}$} & $\begin{array}{c}\text { Mean Conc. } \\
\text { found } \\
(\mathbf{n g} / \mathbf{m L}) \pm \text { SD }\end{array}$ & $\begin{array}{c}\text { Accuracy } \\
(\% \mathbf{~ N )}\end{array}$ & $\begin{array}{c}\text { Precision } \\
(\% \mathbf{C V})\end{array}$ & $\begin{array}{c}\text { Accuracy } \\
(\% \mathbf{\%})\end{array}$ & $\begin{array}{c}\text { Precision } \\
(\% \mathbf{C V})\end{array}$ \\
\cline { 3 - 6 } & 15 & 96.00 & 2.83 & 84.0 & 2.23 \\
750 & $72.83 \pm 0.12$ & 97.81 & 2.78 & 96.36 & 2.92 \\
2500 & $2498 \pm 0.02$ & 99.83 & 0.96 & 98.14 & 2.03 \\
\hline
\end{tabular}

Table 2: Recovery studies for formulation.

\begin{tabular}{|c|c|c|c|c|}
\hline Formulation & $\begin{array}{l}\text { Label } \\
\text { claim }\end{array}$ & $\begin{array}{l}\text { Amount taken for } \\
\text { Assay }(\mathrm{ng} / \mathrm{mL})\end{array}$ & $\begin{array}{l}\text { Amount found } \pm \\
\operatorname{SD}(n=6)\end{array}$ & $\begin{array}{c}\% \\
\text { Recovery }\end{array}$ \\
\hline \multirow{3}{*}{$\mathrm{T}_{1}$} & \multirow{3}{*}{$30 \mathrm{mg}$} & 15 & $14.55 \pm 0.01$ & 97.00 \\
\hline & & 750 & $749.9 \pm 0.03$ & 99.80 \\
\hline & & 2500 & $2499.5 \pm 0.03$ & 99.90 \\
\hline \multirow{3}{*}{$\mathrm{T}_{2}$} & \multirow{3}{*}{$60 \mathrm{mg}$} & 15 & $14.15 \pm 0.01$ & 94.33 \\
\hline & & 750 & $748.45 \pm 0.05$ & 99.79 \\
\hline & & 2500 & $2499.3 \pm 0.15$ & 99.97 \\
\hline
\end{tabular}

\section{Precision}

The precision of the method was determined by the intraday and inter-day precision studies at three different concentrations and they were found to be within the limits (Table 1).

\section{Limit of detection and limit of quantification}

The lowest limit detected for the method for DLP was at $0.3 \mathrm{ng} / \mathrm{mL}$ based on the signal-to-noise ratio 3:1. Due to the increase in the sensitivity of the method, quantification was done at $0.5 \mathrm{ng} / \mathrm{mL}$ for Dexlansoprazole.

\section{Robustness}

The robustness of the method was determined by alteration of the chromatographic conditions and the results obtained were found to be within the limits proving that the developed method was found to be robust.

\section{CONCLUSION}

A novel simple, precise, accurate and a validated, liquid chromatography-tandem mass spectroscopy method has been developed and validated. The developed method can be successfully applied for the estimation of DLP in the commercial formulation and in bulk drug.

\section{CONFLICT OF INTEREST STATEMENT}

The authors declare that there are no conflicts of interest.

\section{ACKNOWLEDGMENT}

The authors are grateful to the Indian Pharmacopeias Commission, New Delhi for providing the standard Dexlansoprazole as a gift sample.

\section{REFERENCES}

Aslam N, Wright RA. Dexlansoprazole MR: Expert Opinion on. Pharmacotherapy, 2009; 10:2329-2336.

Barbara SR, Radwan P. Dexlansoprazole - a new-generation proton pump inhibitor, US National Library of Medicine National Institutes of Health. Prz Gastroenterol, 2015; 10:191-196.

Drug information. [ONLINE] Available at: http://www.drugs com [Accessed 29 Sep 2017].

Hotha KK, Bharathi DV, Jagadeesh B, Ravindranath LK, Jaya Veera KN, Venkateswarulu V. Development and validation of a highly sensitive LC-MS/MS method for quantitation of dexlansoprazole in human plasma: application to a human pharmacokinetic study. Biomed Chromatogr, 2012; 26:192-198.

ICH, Q3B validation of analytical procedures: methodology, International Conference on Harmonization, November 1996. [ONLINE] Available at: https://www.fda.gov/downloads/drugs/guidances/ucm073384. pdf [Accessed 20 Nov 2017].

Metz DC, Vakily M, Dixit T. Dual delayed release formulation of dexlansoprazole MR, a novel approach to overcome the limitations of conventional single release proton pump inhibitor therapy. Aliment Pharmacol Ther, 2009; 29:928-937.

Nagaya H, Satoh H, Maki Y. Possible mechanism for the inhibition of acid formation by proton pump inhibitor AG-1749 in isolated canine parietal cells. J Pharmacol Exp Ther, 1990; 252:1289-1295.

Product information. [ONLINE] Available at: http://www. dexilant.com. [Accessed 15 Sep 2017].

Sriharsha J, Srinivasa MM, Bharat KD, Sravan K, Shiva KP, Shirisha A, Pranusha K. Method for development and validation for simultaneous estimation of dexlansoprazole and meloxicam by RP-HPLC. Pharm Anal Acta, 2015; 26:2153-2435.

Yanamadala G, Srikumar PP, Rushyendra GV, Geetaram Y. Stability indicating validated novel RP-HPLC method for the estimation of dexlansoprazole in bulk and extended release capsules. IAJPR, 2013; $3(10): 8457-8466$.

How to cite this article:

Bora R, Narenderan ST, Babu B, Meyyanathan SN, George AJ, Kalaivani M. Sensitive Analytical Liquid ChromatographyTandem Mass Spectroscopy Method for the Estimation of Dexlansoprazole in Pharmaceutical Formulations. J App Pharm Sci, 2018; 8(07): 033-036. 